\title{
Students in higher education: Social and academic uses of digital technology
}

\author{
Eliana Gallardo Echenique', Luis Marqués Molías² and Mark Bullen ${ }^{3}$ \\ 1. Rovira i Virgili University (URV), Spain | egallardoechenique@gmail.com \\ 2. Rovira i Virgili University (URV), Spain | luis.marques@urv.cat \\ Submitted in: December 2013 \\ 3. Commonwealth of Learning, Canada | mbullen54@gmail.com

\section{Recommended citation}

Gallardo, E., Marqués, L., \& Bullen, M. (2015). Students in higher education: Social and academic uses of digital technology. RUSC. Universities and Knowledge Society Journal, 12(1). pp. 25-37. doi http://dx.doi.org/10.7238/rusc.v12i1.2078

\begin{abstract}
This article presents the results of an in-depth interview of twenty Education students at a public face-to-face university in Catalonia on how they use digital technologies in their social and academic lives. The results show that while students have a certain level of competence in digital technology, the way they use the technologies varies according to their purpose. The results also show that social networks and WhatsApp are the most important applications for students, because they enable them to contact others, communicate with each other over long distances, and contact people with shared interests.
\end{abstract}

\section{Keywords}

digital learners, higher education, digital technology, ICT

\section{El estudiante en la educación superior: Usos académicos y sociales de la tecnología digital}

\section{Resumen}

Este artículo presenta los resultados de una entrevista en profundidad realizada a veinte estudiantes de Educación de una universidad presencial pública de Cataluña sobre cómo utilizan las tecnologías digitales en el aspecto social y académico. Esta investigación demuestra que, si bien los estudiantes tienen un cierto nivel de habilidades en tecnologías digitales, cómo las utilizan varía en función del propósito que ellos les dan o según una tarea determinada. Los resultados expuestos evidencian que las redes sociales y el WhatsApp son las aplicaciones más importantes para los estudiantes porque les permiten ponerse en contacto con otros, comunicarse a pesar de las distancias y estar en contacto con personas con intereses comunes.

\section{Palabras clave}

estudiante digital, educación superior, tecnología digital, TIC 


\section{Introduction}

There is currently a tendency to suggest that today's university students are different from those of previous generations in terms of the way they learn, use digital technology and interact with each other. This idea is so firmly entrenched that many researchers and educators treat it as if it were a self-evident truth. We use the term "digital technology" to refer to a wide range of tools, devices, programs and resources that store and transmit information in digital format, such as computers, the Internet, e-mail, mobile phones and other mobile devices, cameras, video games and what have become known as Web 2.0 technologies (e.g. blogs, wikis and social networks; Abbott, 2007; Hague \& Williamson, 2009).

Several names coined for this generation emphasize their affinity with and tendency to use digital technology. They include "millennials" (Howe \& Strauss, 1991), "the net generation" (N-Gen; Tapscott, 1998), "digital natives" (Prensky, 2001), "digital learners" (Brown, 2000) and "learners of the digital era" (Rapetti \& Cantoni, 2010). The argument runs that today's students start their university studies after having been exposed to a wide range of digital technologies that did not previously exist (Brown \& Czerniewicz, 2010), as they are immersed in Web 2.0 technologies such as Facebook, Twitter, podcasts, wikis, blogs and virtual worlds (Bicen \& Cavus, 2011).

However, the assumption that there is a generation of young people - born between 1980 and 1994 - who are characterized by their familiarity and confidence with digital technologies, and who have different learning styles and behavioural characteristics, has been called into question internationally on the basis of rigorous studies by Bennett, Maton and Kervin (2008), Pedró (2009), Brown and Czerniewicz (2010), Corrin, Lockyer and Bennett (2010), Helsper and Eynon (2010), Kennedy, Judd, Dalgarno and Waycott (2010), Bullen, Morgan and Qayyum (2011), Rapetti (2012), and Romero, Guitert, Sangrà and Bullen (2013). Indeed, some of these studies suggest that students of the same age vary greatly in the way they use technology. Furthermore, the use of digital technologies does not necessarily entail a great deal of knowledge of them, such as knowing programming languages; and the use of such technologies by students does not necessarily imply that they use them when engaged in their academic activities (Bennett et al., 2008; Romero, Guitert, Bullen \& Morgan, 2011).

In fact, some of the authors mentioned above have shown that although there is considerable interest in describing and addressing the learning needs of a generation that has grown up surrounded by technology, there is little empirical basis for most of the statements that have been made. They have shown that there is no evidence to support claims that young students use digital technology in a radically different way to previous generations, and they argue that the characteristics of the net generation can also be found in other generations. Since much of the research has focused on university students in developed countries (e.g. Australia, the United Kingdom, the United States, Canada and Japan), we wondered to what extent these characteristics would also apply in a different social context: a public university in Catalonia (Spain).

\section{Objective}

As discussed above, the aim of this paper is to determine how digital technologies are used for social and academic purposes by Education students at Rovira i Virgili University in order to define specific educational intervention initiatives.

RUSC Vol. 12 No 1 | Universitat Oberta de Catalunya and University of New England | Barcelona, January 2015 


\section{Methodology}

This research falls within the interpretive paradigm and is linked to Max Weber's (1864-1920) concept of verstehen, or "understanding" (Crotty, 1998). This paradigm focuses on the study of the meanings of human actions and social life, that is, social actors' interpretation of their "reality", and emphasizes the researchers' process of understanding in order to attempt to discover the meaning of their actions (Krause, 1995; González, 2003; Daly, 2007). The interpretive paradigm seeks to understand the values, beliefs and meanings of social phenomena by describing and understanding what is individual, unique, particular and singular in phenomena, rather than what is generalizable and universal (Ferguson, 1993; Kim, 2003). According to Willis (2007), the interpretive paradigm favours qualitative methods such as case studies, interviews and observation, because these are the best methods for understanding how humans interpret the world around them.

This research is part of an international project called Digital Learners in Higher Education (http://digitallearners. ca), which aims to understand the use of ICT by students in higher education. The institutions participating in this research were the British Columbia Institute of Technology (BCIT, Canada), the University of Regina (Canada), Rovira i Virgili University (URV, Spain) and the Open University of Catalonia (UOC, Spain).

Our study was conducted at the Faculty of Education Sciences and Psychology of Rovira i Virgili University in Tarragona. "Homogeneous" and "convenience" samples were used, in which groups/individuals were selected according to specific or similar characteristics (homogeneous; Collins, Onwuegbuzie \& Jiao, 2006) and based on their availability and willingness to participate in the study (convenience; Collins, Onwuegbuzie \& Jiao, 2006; Creswell, 2008). The sample consisted of 20 university students in the second year of Pedagogy (55\%), Social Education (35\%), Nursery Education (5\%) and Primary Education (5\%). Most participants were women (70\%), and they ranged in age from 19 to 58. During their first year, these students had previously answered the "Student Communication \& Study Habits" questionnaire, developed by Bullen, Morgan, Belfer and Qayyum (2008), which was used to obtain quantitative information in order to put the problem in an empirical context. Its design and validation is described in Qayyum (2010).

Semi-structured interviews were the main source of data collection. Interviews consisted of 13 standardized open-ended questions that allowed detailed information to be obtained from the students (age, sex, campus, academic programme, frequency and use of technologies, etc.). The instrument used to obtain the information was the interview script developed by Bullen, Morgan, Belfer and Qayyum (2008). This script was adapted and translated into Spanish by experts at the Open University of Catalonia (UOC), and the terminology was adapted to the URV educational model. Detailed information on the content validation criteria is provided in Romero et al. (2013). The questions focused on attempting to identify the digital technologies that students use for academic and social purposes, and how, why and where they use them.

Before the interview started, the students were told about the research process, and verbal consent was obtained from each participant to record all interviews (Cohen, Manion \& Morrison, 2007). During the interviews, the researcher made sure to safeguard the confidentiality and anonymity of the interviewees by using alphanumeric coding (Creswell, 1998; Cohen, Manion \& Morrison, 2007). The 20 interviews produced more than five hours of recordings. Ninety-three pages were transcribed and this material was treated as confidential. After the interviews had been transcribed, they were analyzed and encoded using the Atlas.ti 7.1.5 program for qualitative data analysis.

Thematic analysis of all interviews was conducted for data processing purposes. This method enables patterns and themes to be identified, organized and analyzed in detail based on a careful reading and rereading of the 
information collected. This process makes it possible to infer results and reach a correct understanding/interpretation of the phenomenon being studied (Braun \& Clarke, 2006). The six stages in the process, in which we carried out the thematic analysis with scientific rigour, are set out in Table 1.

Table 1. Data analysis process in the thematic analysis

\begin{tabular}{|l|l|}
\hline \multicolumn{1}{|c|}{ Phase } & \multicolumn{1}{c|}{ Description } \\
\hline Familiarization with the data & Transcription of data (if necessary), reading and rereading of the material and annotation of general ideas. \\
\hline Generation of initial codes & $\begin{array}{l}\text { Systematic encoding of the most relevant aspects of the data throughout the entire data set, and collection } \\
\text { of relevant data for each code. }\end{array}$ \\
\hline Search for themes & Compilation of codes on possible themes and collection of all the relevant data for each theme. \\
\hline Review of themes & $\begin{array}{l}\text { Verification that the themes are functional in relation to the codes extracted (phase 1) and the entire data } \\
\text { set (phase 2), and generation of a thematic "map" of the analysis. }\end{array}$ \\
\hline $\begin{array}{l}\text { Defining and naming of } \\
\text { themes }\end{array}$ & $\begin{array}{l}\text { Ongoing analysis to refine the details of each theme, and generation of clear definitions and names for each } \\
\text { theme. }\end{array}$ \\
\hline Preparation of the report & $\begin{array}{l}\text { Selection of text fragments with the most striking and powerful examples. Final analysis of selected } \\
\text { text fragments related to previous analyses according to the research question(s) and the theoretical } \\
\text { framework. Finally, production of an academic report on the analysis. }\end{array}$ \\
\hline
\end{tabular}

Note. Adapted from “Using thematic analysis in psychology”, by V. Braun and V. Clarke, 2006, Qualitative Research in Psychology, $3(2)$, p. 87.

We encoded and categorized the information, identifying one or more passages of text with a theme and relating it to a code, which was a shorthand reference for the thematic idea (Gibbs, 2012). Figure 1 shows the encoding process for a fragment of interview using the program Atlas.ti. The categories created were: a) meaning of digital technology, b) frequency of use (low, medium and high), c) benefits (social and academic), d) effects (positive and negative), e) uses (social and academic) and f) location (at URV, at home and at work).

Figure 1. Encoding process with Atlas.ti

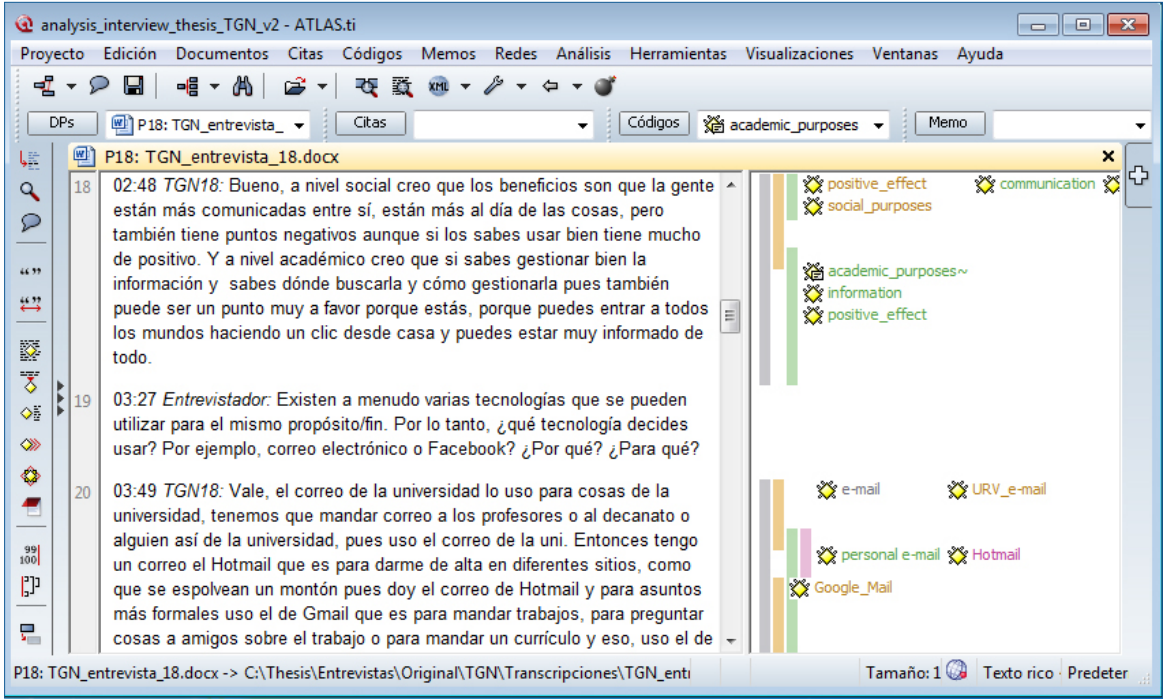


Validity and reliability

Reliability was obtained using two evaluations. The first was in terms of "expert opinion", based on reflection, discussion and criticism (Ahuvia, 2001; Cáceres, 2003) with the lead researcher of the international project and experts from Rovira i Virgili University in Tarragona (Spain) and Ludwig-Maximilians University in Munich (Germany). The second was agreement between the coders, and the result of systematic reflection to define and establish the codes (subcodes) and categories (subcategories). Validity was obtained by means of agreement between coders, wherein an encoder external to the research project agreed to assign the same analysis codes in the same categories as the encoding carried out by the interviewer (Cáceres, 2003; Vaismoradi, Turunen \& Bondas, 2013).

\section{Results, analysis and reflection}

This paper analyzes results corresponding to the first interview questions related to the objectives of this research.

Which digital technologies do you use most often?

Figure 2. Digital technologies that students use most frequently

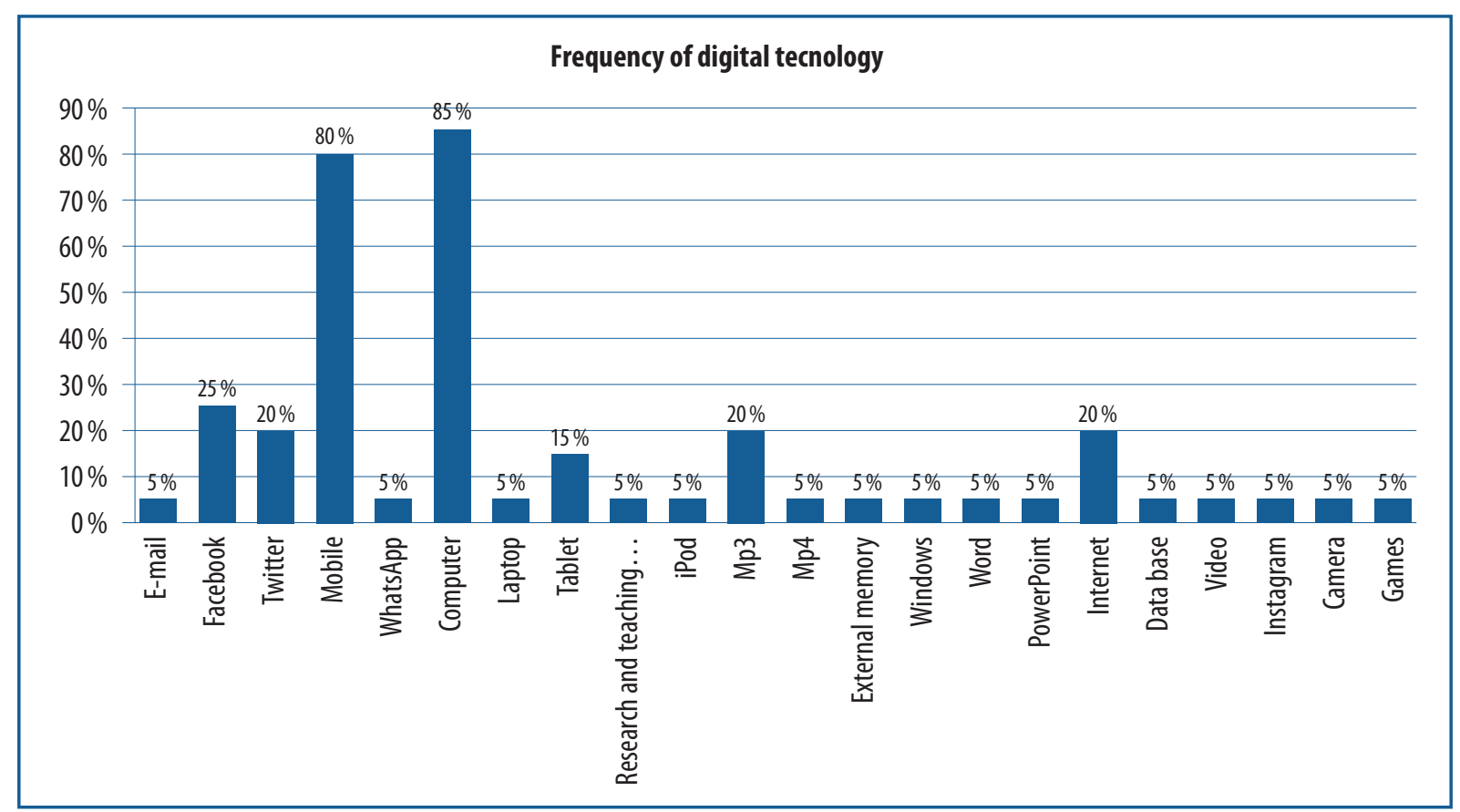

The results show that computers (85\%) and mobile phones (80\%) are the digital technologies that students use most frequently (Figure 2).

"The computer all the time ... Well, the mobile as well because ... Android these days is an essential digital technology in everyday life ..." [Woman, Early Nursery Education, 29 years old] 
"The computer, mobile, camera ... and that's it, because I don't watch television." [Man, Social Education, 22 years old]

"Well, smartphones, the computer, social networks and that's it." [Man, Social Education, 24 years old]

The Internet tool most widely used by students is Facebook (25\%), followed by Twitter (20\%). These results differ from the findings of Bryant, Sanders-Jackson and Smallwood (2006), who found that in addition to e-mail, instant messaging was the most widely used Internet tool. On the other hand, our results are consistent with the findings of Uys et al. (2012), who found that students spent most of their time on their mobile using social networks such as Facebook, Facebook Chat and WhatsApp.

"Well, the mobile, the computer ... Well, on the computer all the applications that are on the mobile as well, and that's

it ... Well, Facebook, Twitter, good game applications ..." [Woman, Pedagogy, 24 years old]

"... mainly I use the Internet with social networks: I'm connected all day, on Facebook, Twitter, WhatsApp, and others that aren't so well known, like Instagram for photos and things like that ..." [Woman, Pedagogy, 20 years old]

Could you please give me some examples of how you use digital technology for social purposes (social life, entertainment) and for academic purposes?

Most of those interviewed, who normally use their computers to access their online learning materials (courses) thanks to mobile technology, have flexible access (independent of time or place) to social networks such as Facebook and Twitter for both social and academic purposes. Based on the students' responses, it appears that most students use social networks as a means of communication. This result is consistent with studies carried out in Singapore (Wang et al., 2012), which have shown that Facebook enables students to communicate and interact with their peers easily, as it appears to be a good tool for supporting communication and social interaction. The students' responses confirm that socialization over the Internet has become an increasingly important part of young people's lives (Kirschner \& Karpinski, 2010). Some of the most significant and relevant responses in terms of the above are listed below (Table 2).

Text messages and chat using mobiles still seem to be the most important functions for many students. Some students mention WhatsApp, a cross-platform messaging application that allows messages to be sent and received free of charge, as another application or communication channel. According to Boase (2013), mobile phones have been limited to call and text messaging functions. However, according to the students' responses, their use ranges from communication and entertainment to social and academic purposes. This might in part be because there are numerous applications available to users, and these devices usually allow Internet access and web browsing, which further increases the scope of their possible activities (Boase, 2013). According to Boneva et al. (2006), students use text messages via their mobile phone and instant messaging to keep in touch with their classmates, as they can have a real-time one-to-one or one-to-many private conversation, which satisfies two major needs by enabling them to form and maintain individual and group friendships.

According to the responses of those interviewed, mobile phones (WhatsApp) and Facebook appear to facilitate interactive work and collaboration by means of simultaneous communication with peers through the creation of working groups. Their responses show that mobile devices, and smartphones in particular, are used as support tools in the learning process. One possible explanation is that mobile devices are the only technologies that we can have with us almost everywhere and at any time. These findings are consistent with the studies by Beurer-Zuellig

RUSC Vol. 12 No 1 | Universitat Oberta de Catalunya and University of New England | Barcelona, January 2015 
and Meckel (2008), Clough et al. (2008) and Wang et al. (2012). According to Beurer-Zuellig and Meckel (2008), the advantages of smartphones in terms of collaborative work are a) the ability to review and archive communication automatically, b) simplification of teams and the coordination of tasks, c) accelerated processes, d) improved accessibility, and e) as a source of updated information.

Table 2. Most common social and academic purposes for digital technologies

\begin{tabular}{|c|c|c|}
\hline Technology & Social purposes & Academic purposes \\
\hline Computer & $\begin{array}{l}\text { Entertainment, listening to music, for example, or watching } \\
\text { films on your computer, or chatting with friends sometimes } \\
\text { - doing all kinds of things like that ... for fun ... [Woman, } \\
\text { Early Childhood Education, } 29 \text { years old] }\end{array}$ & $\begin{array}{l}\text {... academically, the entire computer ... I mean Word, both } \\
\text { in Office and Open Office ... search engines ... [Man, Social } \\
\text { Education, } 22 \text { years old] The computer to find information } \\
\text { for my studies ... [Man, Social Education, } 25 \text { years old] }\end{array}$ \\
\hline Mobile & $\begin{array}{l}\text { The mobile for social networks, social networks to stay } \\
\text { informed, because I also sometimes read the newspaper on } \\
\text { the mobile ... [Man, Social Education, } 25 \text { years old] } \\
\text {...the mobile to communicate with friends and family. } \\
\text { [Woman, Pedagogy, } 26 \text { years old] }\end{array}$ & $\begin{array}{l}\text { I use the smartphone to get in touch with my classmates } \\
\text { academically, because you can look at work, check it over, } \\
\text { and make a minor correction and resend it whenever you } \\
\text { need to. [Man, Social Education, } 24 \text { years old] }\end{array}$ \\
\hline WhatsApp & $\begin{array}{l}\text { WhatsApp is ... well, a revolution, isn't it! ... I use it a lot } \\
\ldots \text {.. to talk to my family, friends ... [Woman, Pedagogy, } 26 \\
\text { years old] }\end{array}$ & $\begin{array}{l}\text { I have WhatsApp. We have special groups for academic } \\
\text { purposes, groups for professional profiles. We're a group and } \\
\text { we use it to communicate with each other to meet, to share } \\
\text { information ... [Man, Social Education, } 22 \text { years old] }\end{array}$ \\
\hline Internet & $\begin{array}{l}\text {... it's much easier to make a reservation ... on the Internet } \\
\ldots \text {.. and I think it's great that you don't have to go to a } \\
\text { ticket office to buy a ticket at the last minute... [Woman, } \\
\text { Pedagogy, } 58 \text { years old] }\end{array}$ & $\begin{array}{l}\text {...I use Explorer, the Internet, and especially the Google } \\
\text { search engine for anything I need to check ... [Woman, } \\
\text { Pedagogy, } 26 \text { years old] }\end{array}$ \\
\hline $\begin{array}{l}\text { Social } \\
\text { networks }\end{array}$ & $\begin{array}{l}\text {...I use social networks ... well, for social contacts, to get } \\
\text { in touch with my colleagues ... [Man, Social Education, } 24 \\
\text { years old] }\end{array}$ & $\begin{array}{l}\text {... social networks to share work more than anything else } \\
\text {... [Woman, Pedagogy, } 26 \text { years old] }\end{array}$ \\
\hline Facebook & $\begin{array}{l}\text { For social purposes, if I've arranged to meet friends and } \\
\text { someone's late, to call them or let them know with a } \\
\text { message or on Facebook, creating events if we arrange to } \\
\text { meet up somewhere. [Woman, Social Education, } 19 \text { years } \\
\text { old] }\end{array}$ & $\begin{array}{l}\text {...I use Facebook to do group tasks ... All the members } \\
\text { who have something new to say or something - we put } \\
\text { it there and we upload it, correct it, talk about it, even the } \\
\text { appointments that we sometimes have, "Ah, Wednesday at } \\
\text { such and such a time!" [Woman, Pedagogy, } 26 \text { years old] }\end{array}$ \\
\hline Tablet & $\begin{array}{l}\text {... I use it for social purposes like connecting to Facebook, } \\
\text { to Twitter, watching news on the Internet ... sports pages, } \\
\text { everything related to the world of the Internet. [Man, } \\
\text { Pedagogy, } 22 \text { years old] }\end{array}$ & $\begin{array}{l}\text {... well, I use Word to take notes, to study as well, for } \\
\text { looking at the presentations that we're going to do, I } \\
\text { have them on my tablet. I use them as a support in our } \\
\text { presentations. [Man, Pedagogy, } 22 \text { years old] }\end{array}$ \\
\hline Moodle & $\begin{array}{l}\text {...to communicate ... with you through the Moodle, don't } \\
\text { I? With lecturers and all that. [Woman, Pedagogy, } 24 \text { years } \\
\text { old] }\end{array}$ & $\begin{array}{l}\text { And the university's intranet ... where you get all the } \\
\text { functions of the courses and stuff. Academically, for that I } \\
\text { suppose, to search for information and ... to upload the } \\
\text { information you're working on as well. [Woman, Early } \\
\text { Childhood Education, } 29 \text { years old] }\end{array}$ \\
\hline
\end{tabular}

Facebook is the most popular of all the social networks, and there is no doubt that like many other new technologies it has considerable potential for teaching and learning based on the integration of its functions, which have educational, social and technological potential (Wang et al., 2012). According to Wang et al. (2012), like any 
new technology, Facebook appears to hold a great deal of potential for teaching and learning, as many students use Facebook every day through Facebook groups that can be used as an alternative system for learning management.

Moodle is the URV's virtual learning environment. However, only a few students mentioned it, and their answers indicate that they see Moodle only as a means of communicating with their teachers. One possible explanation for this could be that Moodle tends to be highly focused on academic work and lacks a personal touch and the capacity for interaction that social networks offer (Brady, Holcomb \& Smith, 2010). Another possible explanation is that social networks can actively promote the construction of online communities and extend learning beyond the confines of the classroom, providing a forum where users can create their own discussions and their own groups, whereas in the Moodle format they depend on the lecturer (Smith, 2009; Brady, Holcomb \& Smith, 2010).

\section{Conclusions}

This research shows that while students have some degree of skill in the use of digital technologies, their frequency of use varies depending on the purpose or particular task for which they use them. For most students, the technological medium is obviously seen as a means for socialization and communication (personal, social and academic) in which social networks - scenarios for social interaction - play an important role. Students see cyberspace as an opportunity to fulfil their communication needs. However, this does not entail a breach with other spaces. These results also show that social networks and WhatsApp are the most important applications for students because they enable them to contact others, communicate with each other over long distances, and stay in touch with people with shared interests, regardless of their physical location.

These results give us an initial insight into how students use technology for academic and social purposes, among others, and how these uses are related. This may be very useful for defining specific educational intervention initiatives and as a point of reflection on the tools that students have fully incorporated into their lives. Finally, it is necessary to promote research and implementation of experiences in social networks that are consciously applied in the university sphere. Universities should therefore position themselves in terms of the use they make of social networks, taking advantage of the positive attitude students have towards these networks and their vast communicative, social and academic potential. This could lead to a rethinking of the educational model and the methodologies associated with this model.

Finally, the results of this study are consistent with findings in other studies (Beurer-Zuellig \& Meckel, 2008; Clough et al., 2008; Thirunarayanan et al., 2011; Uys et al., 2012; Wang et al., 2012), as they highlight the advantages provided by technologies: a) for collaborative work, given their potential for use almost anywhere and at any time; and b) their important role in teaching and learning thanks to the integration of functions, which offers educational, social and technological potential.

\section{Limitations of the study}

One major limitation was the difficulty of having access to the sample, as we had to consider variables such as availability of space and the students'time. The data collected are based on the honesty, transparency and motivation

RUSC Vol. 12 No 1 | Universitat Oberta de Catalunya and University of New England | Barcelona, January 2015 
of those interviewed. Another limitation is that this study evaluates a specific group, namely Education students at URV. These results cannot be generalized to other students, especially those who do not attend university, or to students at other institutions.

\section{Acknowledgements}

The authors wish to thank the reviewers for their valuable contributions and the students who voluntarily participated in this study. Thanks to the researchers of the Applied Research in Education and Technology Group (ARGET) for all their help.

\section{References}

Abbott, C. (2007). E-inclusion: Learning difficulties and digital technologies (Report 15). Bristol, RU. Accessed at http:// archive.futurelab.org.uk/resources/publications-reports-articles/iterature-reviews/Literature-Review314

Ahuvia, A. (2000). Traditional, interpretive, and reception based content analyses: Improving the ability of content analysis to address issues of pragmatic and theoretical concern. Social Indicators Research, 54(2), 139-172. doi: 10.1023/A:1011087813505

Bennett, S., Maton, K., \& Kervin, L. (2008). The "digital natives" debate: A critical review of the evidence. British Journal of Educational Technology, 39(5), 775-786. doi: 10.1111/j.1467-8535.2007.00793.x

Beurer-Zuellig, B., \& Meckel, M. (2008). Smartphones enabling mobile collaboration. Proceedings of the 41st Annual Hawaii International Conference on System Sciences (HICSS 2008) (pp. 49-59). Waikoloa, HI. doi: 10.1109/ HICSS.2008.399

Bicen, H., \& Cavus, N. (2011). Social network sites usage habits of undergraduate students: Case study of Facebook. Procedia - Social and Behavioral Sciences, 28, 943-947. doi: 10.1016/j.sbspro.2011.11.174

Boase, J. (2013). Implications of software-based mobile media for social research. Mobile Media \& Communication, 1(1), 57-62. doi:10.1177/2050157912459500

Boneva, B. S., Quinn, A., Kraut, R., Kiesler, S., \& Shklovsky, I. (2006). Teenage communication in the instant messaging era. In R. Kraut, M. Brynin, \& S. Kiesler (Eds.), Computers, phones, and Internet: Domesticating information technology (pp. 201-218). New York, NY: Oxford University Press.

Brady, K. P., Holcomb, L. B., \& Smith, B. V. (2010). The use of alternative social networking sites in higher educational settings: A case study of the e-learning benefits of Ning in education. Journal of Interactive Online Learning, 9(2), $151-170$.

Braun, V., \& Clarke, V. (2006). Using thematic analysis in psychology. Qualitative Research in Psychology, 3(2), 77-101. doi: 10.1191/1478088706qp063oa

Brown, C., \& Czerniewicz, L. (2010). Debunking the"digital native": Beyond digital apartheid, towards digital democracy [Special section]. Journal of Computer Assisted Learning, 26(5), 357-369. doi: 10.1111/j.1365-2729.2010.00369.x

Brown, J. S. (2000). Growing up digital: How the web changes work, education, and the ways people learn. Change: The Magazine of Higher Learning, 32(2), 11-20. doi: 10.1080/00091380009601719 
Bryant, J. A., Sanders-Jackson, A., \& Smallwood, A. M. K. (2006). IMing, text messaging, and adolescent social networks. Journal of Computer-Mediated Communication, 11(2), 577-592. doi: 10.1111/j.1083-6101.2006.00028.x

Bullen, M., Morgan, T., \& Qayyum, A. (2011). Digital Learners in Higher Education: Generation is not the issue. Canadian Journal of Learning and Technology, 37(1), 1-24.

Bullen, M., Morgan, T., Belfer, K., \& Qayyum, A. A. (2008). The Digital Learner at BCIT and implications for an e-Strategy. Paper presented at the Research Workshop of the European Distance Education Network (EDEN), Researching and promoting access to education and training: The role of distance education and e-learning in technology-enhanced environments. Paris.

Cáceres, P. (2003). Análisis cualitativo de contenido: Una alternativa metodológica alcanzable. Psicoperspectivas. Individuo y Sociedad, 2(1), 53-82.

Clough, G., Jones, A. C., McAndrew, P., \& Scanlon, E. (2008). Informal learning with PDAs and smartphones. Journal of Computer Assisted Learning, 24(5), 359-371. doi: 10.1111/j.1365-2729.2007.00268.x

Collins, K. M. T., Onwuegbuzie, A. J., \& Jiao, Q. G. (2006). Prevalence of mixed-methods sampling designs in Social Science research. Evaluation \& Research in Education, 19(2), 83-101. doi: 10.2167/eri421.0

Corrin, L., Lockyer, L., \& Bennett, S. (2010). Technological diversity: An investigation of students' technology use in everyday life and academic study. Learning, Media and Technology, 35(4), 387-401. doi: 10.1080/ 17439884.2010 .531024

Cohen, L., Manion, L., \& Morrison, K. (2007). Research methods in education (6 $6^{\text {th }}$ ed.). London; New York: Routledge.

Creswell, J. W. (1998). Qualitative inquiry and research design: choosing among five traditions. Thousand Oaks, CA: Sage Publications.

Crotty, M. (1998). The foundations of social research: Meaning and perspective in the research process. Thousand Oaks, CA: Sage Publications.

Daly, K. J. (2007). Qualitative methods for family studies \& human development. Thousand Oaks, CA: Sage Publications. Ferguson, D. L. (1993). Something a little out of the ordinary: Reflections on becoming an interpretivist researcher in special education. Remedial and Special Education, 14(4), 35-43. doi: 10.1177/074193259301400408

Gibbs, G. (2012). El análisis de datos cualitativos en Investigación Cualitativa. Madrid: Ediciones Morata. González, A. (2003). Los paradigmas de investigación en las ciencias sociales. ISLAS, 45(138), 125-135.

Hague, C., \& Williamson, B. (2009). Digital participation, digital literacy and school subjects: A review of the policies, literature and evidence (p. 30). Bristol, RU. Accessed at http://www2.futurelab.org.uk/resources/documents/ lit_reviews/DigitalParticipation.pdf

Helsper, E. J., \& Eynon, R. (2010). Digital natives: Where is the evidence? British Educational Research Journal, 36(3), 503-520. doi: 10.1080/01411920902989227

Howe, N., \& Strauss, W. (1991). Millennials Rising: The Next Great Generation. New York: Vintage Original.

Kennedy, G., Judd, T., Dalgarno, B., \& Waycott, J. (2010). Beyond natives and immigrants: exploring types of net generation students. Journal of Computer Assisted Learning, 26(5), 332-343. doi: 10.1111/j.1365-2729.2010.00371.x

Kim, S. (2003). Research paradigms in organizational learning and performance: Competing modes of inquiry. Information Technology, Learning, and Performance Journal, 21(1), 9-18.

Kirschner, P. A., \& Karpinski, A. C. (2010). Facebook ${ }^{\circledR}$ and academic performance. Computers in Human Behavior, 26(6), 1237-1245. doi: 10.1016/j.chb.2010.03.024

Krause, M. (1995). La investigación cualitativa: un campo de posibilidades y desafíos. Revista Temas de Educación, (7), $19-36$

RUSC Vol. 12 No 1 | Universitat Oberta de Catalunya and University of New England | Barcelona, January 2015 
Kvale, S. (2011). Las entrevistas en investigación cualitativa. Madrid: Morata.

Pedró, F. (2009). New Millennium learners in higher education: Evidence and policy implications. Paper presented at The International Conference on 21st Century Competencies, Brussels: OECD/CERI.

Prensky, M. (2001). Digital natives, digital immigrants part 1. On the Horizon, 9(5), 1-6. doi: 10.1108/10748120110424816 Rapetti, E., \& Cantoni, L. (2010). "Digital Natives" and learning with the ICTs. The "GenY @ work" research in Ticino, Switzerland. Journal of E-Learning and Knowledge Society, 6(1), 39-49.

Rapetti, E. (2012). LoDE: Learners of Digital Era (Doctoral dissertation). Università della Svizzera italiana. Accessed at: RERO DOC: Library Network of Western Switzerland (2012COM006).

Romero, M., Guitert, M., Bullen, M., \& Morgan, T. (2011). Learning in digital: An approach to digital learners in the UOC scenario [Special issue]. European Journal of Open, Distance and E-Learning, 1-8. Accessed at http://www.eurodl. org/?article $=440$

Romero, M., Guitert, M., Sangrà, A., \& Bullen, M. (2013). Do UOC students fit in the Net generation profile? An approach to their habits in ICT use. The International Review of Research in Open and Distance Learning, 14(3), 158-181. Accessed at http://www.irrodl.org/index.php/irrodl/article/view/1422/2529

Smith, B. V. (2009). Use of online educational social networking in a school environment (Master's thesis). North Carolina State University. Accessed at: NC State Theses and Dissertations, http://www.lib.ncsu.edu/resolver/1840.16/900 Tapscott, D. (1998). Growing up digital: the rise of the Net generation. New York: McGraw-Hill.

Thirunarayanan, M. O., Lezcano, H., McKee, M., \& Roque, G. (2011). "Digital nerds" and "Digital normals": Not "Digital natives" and "Digital immigrants". International Journal of Instructional Technology and Distance Learning, 8(2). Accessed at http://www.itdl.org/Journal/Feb_11/article03.htm

Uys, W., Mia, A., Jansen, G. J., Schyff, H. van der, Josias, M. A., Khusu, M., \& Samsodien, Y. (2012). Smartphone application usage amongst students at a South African University. In P. Cunningham and M. Cunningham (Eds.). IST-Africa 2012 Conference Proceedings (pp. 1-11). Cape Town, South Africa: IIMC International Information Management Corporation.

Vaismoradi, M., Turunen, H. , \& Bondas, T. (2013). Content analysis and thematic analysis: Implications for conducting a qualitative descriptive study. Nursing \& Health Sciences, (15), 398-405. doi: 10.1111/nhs.12048

Wang, Q., Woo, H. L., Quek, C. L., Yang, Y., \& Liu, M. (2012). Using the Facebook group as a learning management system: An exploratory study. British Journal of Educational Technology, 43(3), 428-438. doi: 10.1111/j.14678535.2011.01195.x

Willis, J. W. (2007). Foundations of qualitative research: Interpretive and critical approaches (p. 392). Thousand Oaks, CA: Sage Publications. 


\section{About the authors \\ Eliana Gallardo Echenique \\ egallardoechenique@gmail.com \\ Doctor in Educational Technologies, URV}

She holds a degree in Communication Science and a master's degree in Educational Technologies: e-learning and knowledge management. She was a consultant and specialist in educational technology at the Ministry of Education of Peru for nearly ten years. She has been involved in the design and implementation of several research projects and programmes related to information and communication technologies applied to education, the development of educational materials, and the development of teacher training courses. Doctorate in Educational Technologies and she received a grant from the Government of Catalonia FPI Fellow (training of research personnel) at the Department of Pedagogy at Rovira i Virgili University (Spain). She is a member of the ARGET (Applied Research in Education and Technology Group) research group (ref. 2009SGR596).

Rovira i Virgili University Department of Pedagogy

Sescelades Campus

Carretera de Valls, s/n

43007 Tarragona

Spain

Luis Marqués Molías

luis.marques@urv.cat

Dean, Faculty of Education Sciences and Psychology, URV

He holds a degree in Physical Education from the University of Barcelona, a doctorate in Physical Activities and Sports Science from the University of Zaragoza (2002) and a master's degree in Educational Technology: e-learning and knowledge management from Rovira i Virgili University in Tarragona. His research takes place within the ARGET group, in which he is involved in various research projects and supervises several doctoral theses and master's degree final projects. His work and research lines are in the areas of ongoing teacher training, distance learning and new information and communication technologies applied to education. He has been dean of the URV's Faculty of Education Sciences and Psychology since July 2014

Rovira i Virgili University Department of Pedagogy

Sescelades Campus

Carretera de Valls, s/n

43007 Tarragona

Spain 


\section{Mark Bullen}

mbullen54@gmail.com

Specialist in education and e-learning at the Commonwealth of Learning

Doctorate in Adult Education (1997) from the University of British Columbia (UBC). He is currently a specialist in education and e-learning at the Commonwealth of Learning. He was Dean of the Learning and Teaching Centre at the British Columbia Institute of Technology (BCIT) from 2005 to 2012. He is currently an adjunct lecturer on the master's degree course in Educational Technology at the UBC and on the master's degree course in Distance Education at Athabasca University (Canada). He is also the editor of the Journal of Distance Education, published by the Canadian Network for Innovation in Education. Over the past thirty years, he has worked in the fields of distance education and educational technology in the field of higher education in Canada, and as a consultant for educational organizations worldwide.

2416 W. 8th Ave

Vancouver, BC

V6K 2B1

Canada 